\title{
PENGARUH KETERAMPILAN INTRAPERSONAL DAN INTERPERSONAL TERHADAP PRESTASI WARGA BELAJAR KESETARAAN PAKET C DI PKBM SE-KECAMATAN LOWOKWARU MALANG
}

\author{
Savira Nailul Muna \\ Jurusan Pendidikan Luar Sekolah \\ savira.nay36@gmail.com
}

\begin{abstract}
The purpose of the study was to find out a description level of intrapersonal skills, interpersonal skills, learning achievement and explain the influence of intrapersonal skills, interpersonal skills, on the achievement of the citizen learning equality package $C$ in the PKBM of Lowokwaru Subdistrict Malang. The research approach that has been used is a quantitative approach with a form of correlational research design. The selection of research subjects using a purposive sampling technique by selecting 80 study residents who are citizens of learning parity C package and recorded having a report card in PKBM of Lowokwaru District. The instruments used in this study were inventory of intrapersonal, interpersonal skills, non-academic achievements and documentation studies in the form of report cards. Hypothesis testing used with Kendall Coeficient of Concordance nonparametric statistical analysis techniques. The results showed that the condition of intrapersonal, interpersonal, and learning achievement tends to be high. There is no significant effect between intrapersonal skills on learning achievement. There is no significant effect between interpersonal skills on learning achievement. However, the results of the study also prove that there is an influence between intrapersonal and interpersonal skills on the learning achievement of PKBM learning citizen in Lowokwaru Subdistrict Malang.
\end{abstract}

Keywords: intrapersonality, interpersonality, equality of package C, PKBM

Abstrak: Tujuan penelitian yaitu untuk mengetahui gambaran tingkat keterampilan intrapersonal, interpersonal, prestasi belajar warga belajar dan menjelaskan pengaruh keterampilan intrapersonal, keterampilan interpersonal, terhadap prestasi warga belajar kesetaraan paket C di PKBM Se-Kecamatan Lowokwaru Malang. Pendekatan penelitian yang digunakan adalah pendekatan kuantitatif dengan bentuk desain penelitian korelasional. Pemilihan subjek penelitian menggunakan teknik purposive sampling dengan memilih 80 warga belajar yang merupakan warga belajar kesetaraan paket $\mathrm{C}$ dan tercatat memiliki raport di PKBM Se-Kecamatan Lowokwaru. Instrumen yang digunakan pada penelitian ini yaitu inventori keterampilan intrapersonal, interpersonal, prestasi non akademik dan studi dokumentasi berupa raport. Pengujian hipotesis dilakukan dengan teknik analisis statistika nonparametrik Kendall Coeficient of Concordance. Hasil penelitian menunjukkan bahwa gambaran kondisi intrapersonal, interpersonal, dan prestasi belajar cenderung tinggi. Tidak ada pengaruh yang signifikan antara keterampilan intrapersonal terhadap prestasi belajar. Tidak ada pengaruh yang signifikan antara keterampilan interpersonal terhadap prestasi belajar. Meskipun demikian, hasil penelitian juga membuktikan bahwa terdapat pengaruh antara keterampilan intrapersonal dan interpersonal terhadap prestasi belajar warga belajar PKBM se Kecamatan Lowokwaru Malang.

Kata Kunci: Kompetensi Fasilitator, Motivasi Belajar, Hasil Belajar

\section{PENDAHULUAN}

Manusia sebagai makhluk sosial membutuhkan orang lain dalam memenuhi kebutuhan hidup. Kebutuhan hidup tersebut sangat beragam. Mulai dari kebutuhan primer, sekunder, dan tersier. Manusia dituntut untuk 
memenuhi kebutuhan tersebut agar proses dinamika kehidupan dapat terus berjalan. Dalam penemuhan kebutuhan itu akan terjadi suatu interaksi sosial antara individu satu dengan individu yang lain. Bentuk interaksi sosial seorang individu tentunya beraneka ragam. Keanekaragaman interkasi sosial tersebut berupa kontak dan komunikasi (Rakhmat, 2000:7). Kontak dan komunikasi dapat dilakukan secara langsung dan tidak langsung. Dua hal ini juga menjadi jembatan untuk individu agar dapat diterima oleh lingkungannya.

Individu dapat diterima di lingkungan (masyarakat) jika individu tersebut mampu beradaptasi di lingkunganya. Proses adaptasi tersebut dapat dilakukan individu dengan melakukan interaksi dengan individu yang lain. Akan tetapi, bentuk lingkungan sangat luas, yang terbagi menjadi tiga yaitu keluarga, sekolah, dan masyarakat. Oleh karena itu, individu harus bisa bersosialisasi sejak dini. Hal itu dikarenakan ketika individu tersebut telah dewasa, ia akan dituntut untuk bisa berbaur dengan masyarakat.

Individu yang telah memasuki usia dewasa perlu untuk mendapatkan pendidikan guna untuk meningkatkan kualitas hidupnya. Seperti yang dikemukakan oleh Arif (1986:2) bahwa orang dewasa memiliki konsep diri yang lebih mandiri, di mana orang dewasa telah mempunyai kemauan sendiri untuk belajar. Orang dewasa juga beranggapan untuk mencari pengalaman dan segera mengaplikasikan apa yang telah mereka pelajari. Semua hal tersebut dapat diperoleh oleh orang dewasa dalam dunia pendidikan.

Kamil (2011:1) mengemukakan bahwa pendidikan formal, informal, dan non formal menjadi bagian dari continuing education dan lifelong education sehingga ketiga-tiganya tidak dapat terpisahkan dan tidak dapat berdiri sendiri. Hal itu dikarenakan ketiga-tiganya saling mengisi untuk memenuhi kebutuhan belajar masyarakat yang salah satunya yaitu orang dewasa. Orang dewasa memerlukan keterampilan dan pemahaman untuk mencapai kualitas hidup yang baik. Oleh karena itu, dibutuhkan suatu lembaga pendidikan nonformal yang menjadi sarana pusat pembelajaran dalam masyarakat.

Salah satu pendidikan nonformal yaitu PKBM. Kamil (2011:80) mengemukakan bahwa PKBM merupakan sebuah lembaga pendidikan yang memiliki tujuan untuk mencerdaskan kehidupan masyarakat melalui program-program pendidikan nonformal, diharapkan mampu menumbuhkan masyarakat belajar (learning society). Melalui lembaga PKBM, masyarakat dapat meningkatkan kemandirian, keberdayadidikan, dan inovatif dalam mencari berbagai informasi baru dalam rangka meningkatkan kuliatas kehidupannya.

Selama menempuh pendidikan di PKBM, masyarakat atau lebih dikenal dengan warga belajar tidak terlepas dari suatu pengalaman. Pengalaman tersebut berupa pengalaman positif dan negatif yang dialami oleh warga belajar. Hal ini berkaitan dengan pengalaman bersosialisasi antara warga belajar satu dengan warga belajar yang lain. Fenomena ini juga dialami oleh warga belajar di salah satu PKBM di Kota Malang, yaitu PKBM Kartini yang terletak di JL. Akordion XI, No. 120 RT. 07 RW. 01, Tasikmadu, Kec. Lowokwaru, Kota Malang, Jawa Timur (65143).

Hasil wawancara yang telah dilakukan peneliti pada tanggal 25 Oktober 2018 dengan pemilik PKBM Kartini yaitu PKBM Kartini merupakan PKBM yang berdiri sejak 17 Juli 2001. PKBM Kartini memiliki warga belajar sebanyak 102 warga belajar. Karakteristik warga belajar pun beraneka ragam. Ada yang dapat berinteraksi dengan warga belajar lain dan ada juga yang mengalami kesulitan untuk berinteraksi dengan warga belajar lain. Ketika pertama kali memasuki PKBM, warga belajar paket $\mathrm{C}$ cenderung diam, baik dalam mengikuti pembelajaran maupun berkumpul dengan wajar belajar yang lain. Akibatnya butuh waktu tersendiri bagi warga belajar paket C PKBM Kartini untuk dapat beradaptasi dengan lingkungan PKBM.

Fenomena di atas juga menunjukan adanya keterampilan intrapersonal yang rendah. Hal itu dikarenakan warga belajar 
paket $\mathrm{C}$ menunjukan rasa yang tidak percaya diri dengan cenderung diam. Ini membuktikan adanya keterkaitan dengan keterampilan intrapersonal. Armstrong (2002:34) mengemukakan bahwa keterampilan intrapersonal individu merupakan kemampuan individu untuk mengetahui siapa diri mereka dan apa yang bisa mereka bisa capai di dunia. Dengan kata lain, semakin tinggi keterampilan intrapersonal dalam belajar, semakin tinggi pula tingkat belajar warga belajar tersebut.

Selain kemampuan intrapersonal, fenomena di atas menunjukan adanya keterampilan interpersonal yang dimiliki warga belajar paket C. Interpersonal merupakan jumlah keseluruhan dari kemampuan seseorang untuk berinteraksi secara efektif dengan orang lain (Johnson, 1940:16). Setiap individu memiliki kemampuan interpersonal yang berbeda-beda. Hal itu dikarenakan setiap warga belajar membutuhkan waktu yang berbeda-beda pula untuk dapat bersosialisasi dengan warga belajar lain. Perbedaan ini menjadi dapat menjadi keunikan setiap individu khususnya warga belajar di PKBM.

Kurangnya keterampilan intrapersonal dan interpersonal pada warga belajar akan mengakibatkan terganggunya prestasi warga belajar paket C. Hal itu dikarenakan keterampilan intrapersonal dan interpersonal berpengaruh terhadap prestasi warga belajar. Jika tingkat keterampilan intrapersonal dan interpersonal warga belajar cenderung tinggi maka mengakibatkan prestasi belajarnya juga tinggi. Begitu juga sebaliknya, jika tingkat keterampilan intrapersonal dan interpersonal warga belajar cenderung rendah, maka mengakibatkan prestasi belajarnya juga rendah.

Kebanyakan warga belajar paket C memiliki usia yang menuju ke masa dewasa awal. Mereka memiliki tujuan untuk menumbuhkan keterampilan yang dimiliki agar memperoleh lebih banyak pengalaman dalam pembelajaran. Pengalaman orang dewasa berbeda dengan pengalaman anakanak. Hal ini sesuai dengan karakteristik warga belajar orang dewasa. Smith (dalam Basleman, 2011:28) mengemukakan bahwa salah satu karakteristik warga belajar dewasa yaitu pada akumulasi pengalaman yang lebih menekankan kesukaan pada keuntungal potensial.

Pengalaman-pengalaman yang dialami warga belajar paket $\mathrm{C}$ juga akan mengakibatkan pada gaya belajar ketika pembelajaran di PKBM. Basleman (2011:16) mengemukakan bahwa semua orang dewasa cenderung memperlihatkan keunikan gaya belajar ketika ia melakukan kegiatan belajar. Keunikan itu juga berlatar pada pengalamanpengalaman belajar yang telah diperolehnya sejak lahir. Dengan begitu, dengan adanya pengalaman-pengalaman yang dimiliki, dapat menjadi bekal warga belajar paket $\mathrm{C}$ untuk memahami antara keterampilan-keterampilan yang dimilikinya (intrapersonal dan interpersonal) dengan prestasi belajar yang diraihnya di PKBM. Hal ini sependapat dengan yang dikemukakan oleh Mulyono (2008:188) bahwa prestasi belajar dapat diketahui melalui adanya dua macam prestasi, yaitu prestasi akademik dan prestasi non akademik.

Penelitian terdahulu membuktikan adanya pengaruh keterampilan intrapersonal dan interpersonal terhadap prestasi belajar. Seperti yang dilakukan oleh Imroatusholikhah (2016) yang juga meneliti variabel penelitian yang sama. Imroatusholikhah (2016) mengungkapkan bahwa terdapat pengaruh yang signifikan dari keterampilan intrapersonal dan interpersonal terhadap hasil belajar siswa di pendidikan formal. Hal ini menumbuhkan asumsi baru bahwa hal tersebut juga dapat terjadi serupa di pendidikan nonformal.

Berdasarkan uraian latar belakang di atas, penulis sangat tertarik untuk meneliti bagaimana keterampilan intrapersonal dan interpersonal mempengaruhi prestasi belajar di pendidikan nonformal dengan judul "Pengaruh Keterampilan Intrapersonal dan Interpersonal Terhadap Prestasi Warga Belajar Kesetaraan 
Paket C Di PKBM Se-Kecamatan Lowokwaru Malang".

Perkembangan individu mulai dari balita, anak, remaja, hingga orang dewasa selalu belajar. Tentunya dalam konteks ini belajar untuk menjadi seorang manusia yang baik. Burton 1 (dalam Basleman, 2011:7) mengemukakan bahwa belajara identik dengan suatu perubahan dalam diri individu sebagai hasil interaksinya dengan lingkungannya untuk memenuhi kebutuhan dan menjadikannya lebih mampu melestarikan lingkungannya secara memadai. Berbeda pendapat dengan Burton, Winkel (1991) mengemukakan bahwa belajar adalah suatu aktivitas mental atau psikis yang berlangsung dalam interaksi aktif dengan lingkungan yang menghasilkan perubahan dalam pengetahuan, pemahaman, keterampilan dan nilai sikap. Berdasarkan dua pendapat ahli tersebut, dapat disimpulkan bahwa definisi belajar merupakan perubahan tingkah laku oleh individu dalam berinteraksi dengan lingkungan untuk meningkatkan keterampilan yang dimilikinya.

Sedangkan kata "prestasi" berasal dari Belanda yang disebut prestatie. Jika diterjemahkan dalam bahasa Indonesia, kata tersebut berubah menjadi "prestasi" yang berarti "hasil usaha". Hasil usaha ini seringkali dikaitkan dengan bidang pendidikan. Seperti yang dikemukakan oleh Arifin (1998:3) bahwa prestasi merupakan suatu hasil dari kemampuan, dan sikap seseorang dalam menyelesaikan suatu hal.

Selain itu, pengertian prestasi belajar merupakan hasil usaha individu yang dioperasionalkan dalam bentuk indikatorindikator berupa nilai rapor, indeks prestasi studi, angka kelulusan, predikat keberhasilan, dan semacamnya (Azwar, 1996:164). Mulyono (2008:188) mengemukakan bahwa prestasi belajar merupakan hasil capaian individu yang dibuktikan dengan adanya dua macam prestasi, yaitu prestasi akademik dan prestasi non akademik. Sedangkan Arifin (1998:3) mengemukakan bahwa prestasi belajar merupakan suatu masalah yang bersifat perenial dalam sejarah kehidupan individu. Hal itu dikarenakan kehadiran prestasi belajar dalam kehidupan individunya selalu mengejar prestasi menurut bidang dan kemampuan masing-masing. Berdasarkan dua pendapat di atas dapat diambil kesimpulan bahwa prestasi belajar merupakan hasil usaha individu yang dapat diukur dalam bentuk nilai atau penghargaan dan dapat memberikan kepuasan tertentu pada individu sebagai bentuk interaksi dengan lingkungan.

Arifin (1998:3) mengemukakan bahwa terdapat lima fungsi utama dalam prestasi belajar yaitu 1) prestasi belajar merupakan indikator kualitas dan kuantitas pengetahuan yang telah dikuasai individu, 2) prestasi belajar sebagai lambang pemuasan hasrat ingin tahu, 3) prestasi belajar sebagai bahan informasi dalam inovasi pendidikan, 4) prestasi belajar sebagai indikator intern dan ekstern dari suatu institusi pendidikan, dan 5) prestasi belajar dapat dijadikan indikator terhadap daya serap (kecerdasan) individu.

Faktor yang mempengaruhi prestasi belajar menurut Basleman (2011:29) terbagi menjadi dua yaitu faktor internal dan eksternal. Faktor internal merupakan faktor yang berasal dari dalam diri individu. Faktor internal meliputi faktor fisiologis dan faktor psikologis. Sedangkan faktor eksternal merupakan faktor yang berasal dari luar diri individu. Faktor eksternal meliputi faktor lingkungan belajar dan faktor sistem penyajian.

Dalam faktor fisiologis, strategi belajar dan membelajarkan apapun dan metode penyajian apapun yang digunakan, peran pendengaran dan penglihatan sangatlah penting dalam proses interaksi belajar. Oleh karena itu, tutor atau fasilitator perlu memiliki pengetahuan yang memadai mengenai penglihatan dan pendengran agar strategi belajar dan membelajarkan dipilih dapat secara optimal membantu proses interaksi belajar sehingga hasilnya dapat lebih efektif dan efisien. Sedangkan dalam faktor psikologis, terdapat beberapa aspek yang mempengaruhi proses interaksi warga belajar yang meliputi kecerdasan atau bakat, 
motivasi, perhatian, berpikir, ingatan, belajar lanjut, dan reviu atau resitasi.

Faktor pertama yaitu kecerdasan/bakat yang merupakan salah satu faktor yang menentukan berhasil atau tidaknya seseorang dalam mengikuti suatu kegiatan tertentu. Tugas pendidik atau tutor ialah mengembangkan seoptimal mungkin potensi kecerdasan atau bakat warga belajar dalam mempelajari suatu bahan ajar.

Faktor kedua yaitu motivasi yang merupakan keadaan dalam diri seseorang yang mendorongnya untuk bertindak melakukan suatu kegiatan dalam mencapai tujuan. Motivasi tersebut mempunyai beberapa tujuan, yaitu memberikan semangat untuk meningkatkan kemampuan belajar, meningkatkan saling pengertian dan interaksi antara subjek dan objek didik, meningkatkan efektivitas dan efesiensi pelaksanaan kegiatan untuk mencapai tujuan yang diinginkan.

Selain itu, terdapat pula bentuk-bentuk dari motivasi, yaitu : motivasi internal atau motivasi intrinsik tumbuh dalam diri warga belajar, motivasi eksternal atau motivasi ekstrinsik timbul karena rangsangan dari luar. Daya tahan dan intensitas motivasi eksternal agak kurang dibandingkan dengan motivasi internal, tetapi dalam kenyataannya seseorang tidak selamanya memiliki motivasi yang terakhir ini. Oleh karena itu, tutor atau fasilitator hendaknya berusaha membantu menimbulkan motivasi internal dalam diri warga belajar.

Faktor ketiga yaitu perhatian yang dapat diartikan sebagai pemusatan energi psikis yang dilakukan secara sadar terhadap sesuatu (objek/materi/pelajaran). Terdapat beberapa jenis perhatian, yaitu perhatian disengaja yang timbul karena diprogramkan, perhatian spontan yang timbul tiba-tiba tanpa direncanakan, perhatian intensif timbul karena berkait dengan kebutuhan kegemaran atau kepentingan, perhatian memusat timbul karena objek yang sedang diperhatikan menuntut ketelitian dan kecerdasan khusus dan objek itu tak dapat dirangkaikan dengan objek lain, perhatian memencar timbul karena banyaknya objek yang harus dilakukan sekaligus sejalan dengan tuntutan kegiatan yang dilaksanakan.

Faktor kempat yaitu berpikir yang merupakan suatu kegiatan mental yang berupa upaya melukiskan gagasan berdasarkan pengetahuan yang dimiliki dengan memperhitungkan hubungan sebab akibat dan dirangkaikan secara logis dan rasional. Faktor kelima yaitu ingatan atau memori yang merupakan suatu kegiatan yang memungkinkan seeorang dapat mengemukakan kembali pengetahuan yang telah dimilikinya. Mengingat merupakan kemampuan untuk mengemukakan kembali pengetahuan atau pengalaman yang telah diperoleh.

Faktor keenam yaitu overlearning (belajar lanjut) yang merupakan kegiatan belajar yang dilakukan setelah materi yang dipelajari dapat terhafal untuk pertama kalinya tanpa salah. Pada kegiatan belajar lanjut berlaku pula hukum kenakan hasil yang selalu berkurang. Artinya, kenaikan jumlah pengulangan tidak seimbang dengan kenaikan jumlah unsur pengetahuan yang tersimpan dalam ingatan. Sedangkah faktor ketujuh yaitu reviu/resitasi yang merupakan suatu cara belajar yang dilakukan untuk memproduksi pelajaran yang aktif, baik dalam bentuk lisan maupun dalam bentuk tulisan.

Faktor lingkungan belajar dalam faktor eksternal meliputi lingkungan belajar dan sistem penyajian. Lingkungan belajar dapat dibedakan atas lingkungan dalam kampus tempat belajar dan lingkungan luar kampus atau tempat belajar, masing-masing dapat dibedakan lagi atas lingkungan alam, fisik, dan sosial.

Sedangkan sistem penyajian lebih menekankan pada sistem pembelajaran pendidikan luar sekolah dapat memengaruhi proses interaksi belajar antara lain kurikulum, bahan pelajaran, dan metode penyajian. Selain itu, struktur kurikulum dalam kurikulum inti turut menentukan pemilihan strategi belajar dan membelajarkan suatu mata pelajaran. Dengan struktur tersebut, Dapat diketahui kedudukan dan peranan setiap mata pelajaran 
dalam pembentukan kompetensi: pribadi, pengetahuan, keterampilan, dan sosial.

Bahan belajar juga memiliki peran penting di mana akan disajikan mempengaruhi dalam pemilihan jenis strategi belajar dan membelajarkan yang akan digunakan. Bahan belajar yang perlu dipertimbangkan dalam pemilihan strategi belajar dan membelajarkan yang akan digunakan yaitu ranah tingkah laku (aspek kemampuan), derajat kesukaran bahan, jenis bahan, luas dan jumlah bahan, letak bagian dalam keseluruhan pelajaran.

Metode penyajian yang digunakan berkaitan erat dengan strategi serta kegiatan belajar dan membelajarkan yang dipilih dan dilaksanakan untuk mencapai tujuan pengajaran. Beberapa kriteria pemilihan metode penyajian yang menunjang startegi dan proses interaksi belajar, antara lain: metode penyajian yang dipilih sesuai dengan sifat dan hakikat tujuan pembelajaran yang ingin dicapai, metode penyajian yang dipilih sesuai dengan sifat dan hakikat bahan belajar yang disajikan, metode penyajian yang dipilih sesuai dengan tingkat perkembangan belajar.

Segala kegiatan belajar dan membelajarkan, termasuk pendengaran dan penglihatan pada waktu belajar dipengaruhi oleh kondisi fisiologis, yaitu kesegaran jasmani, keletihan, kurang gizi, kurang tidur, atau sakit yang diderita. Dengan kata lain, kondisi fisiologis pada umumnya memengaruhi proses interaksi belajar. Oleh karena itu, hal itu perlu dipertimbangkan dalam pemilihan startegi belajar membelajarkan.

Mulyono (2008:188) mengemukakan prestasi belajar dapat diketahui berdasarkan dua indikator. Adapun dua indikator tersebut yaitu (1) prestasi belajar akademik dan (2) prestasi belajar non akademik. Prestasi belajar akademik merupakan hasil capaian peserta didik yang diperoleh ketika sedang menempuh pendidikan di dalam jam kegiatan sekolah. Sedangkan prestasi belajar non akademik merupakan hasil capaian peserta didik yang diperoleh ketika di luar jam akademik di sekolah.
Gardner (1993:9) mengemukakan bahwa keterampilan intrapersonal adalah kemampuan korelatif yang berubah ke dalam diri individu. Lebih lanjut, Gardner (1993:24) menjelaskan bahwa keterampilan intrapersonal lebih menekankan pada pengetahuan tentang aspek internal seseorang. Individu memiliki akses ke kehidupan perasaannya, rentang emosinya, kapasitasnya untuk melakukan diskriminasi di antara berbagai macam emosi dan akhirnya memberi label kepada emosi yang muncul. Individu memanfaatkan keterampilan intrapersonal sebagai sarana untuk memahami dan membimbing perilakunya.

Lwin dkk. (2003:33) mengemukakan bahwa keterampilan intrapersonal merupakan keterampilan mengenai diri sendiri. Maksudnya keterampilan ini berfokus pada kemampuan individu untuk memahami dirinya dan bertanggung jawab atas kehidupannya sendiri. Individu selalu berfokus pada pemikiran, gagasan dan impian yang mereka miliki. Selain itu, keterampilan intrapersonal yang dimiliki individu dapat mengarahkan emosi mereka sendiri sedemikian rupa untuk memperkaya dan membimbing kehidupan mereka.

Gunawan (2004:114) mengemukakan bahwa terdapat sepuluh ciri-ciri individu yang memiliki keterampilan intrapersonal. Adapun ciri-ciri individu yang memiliki keterampilan intrapersonal yaitu : (1) Mampu menyadari dan mengerti arti emosi diri sendiri dan emosi orang lain, (2) Mampu mengungkapkan dan menyalurkan perasaan dan pikiran, (3) Mengembangkan konsep diri yang baik dan benar, (4) Termotivasi untuk menentukan dan mengejar suatu tujuan hidup, (5) Menetapkan dan hidup dengan sistem nilai yang sesuai dengan etika, (6) Mampu bekerja secara mandiri, (7) Sangat tertarik dengan pertanyaan arti hidup, tujuan hidup, dan relevansinya dengan keadaan saat ini, (8) Mampu mengembangkan kemampuan belajar yang berkelanjutan dan meningkatkan diri, (9) Tertarik menerjuni karir sebagai pelatih, konselor, filsuf, psikolog, atau memilih jalur spiritual, (10) Mampu menyelami atau 
mengerti kerumitan suatu pribadi dan kondisi manusia pada umumnya.

$$
\text { Armstrong (2002:5) juga }
$$

mengemukakan bahwa ciri-ciri individu yang memiliki keterampilan intrapersonal yang baik. Yaitu memiliki keterampilan intrapersonal yang baik dapat dengan mudah mengakses perasaannya sendiri, membedakan berbagai macam keadaan emosi, dan menggunakan pemahamannya sendiri untuk memperkaya dan membimbing hidupnya. Individu juga sangat mandiri, sangat terfokus pada tujuan dan sangat disiplin.

Lebih lanjut, Armstrong (2002:5) mengemukakan bahwa terdapat rumusan lima indikator dari individu yang memiliki keterampilan intrapersonal yang baik. Individu yang memiliki keterampilan intrapersonal yang baik dapat dengan mudah mengakses perasaannya sendiri, membedakan berbagai macam keadaan emosi, dan menggunakan pemahamannya sendiri untuk memperkaya dan membimbing hidupnya. Individu juga sangat mandiri, sangat terfokus pada tujuan dan sangat disiplin.

Gardner (1993:9) mengemukakan bahwa keterampilan interpersonal merupakan kemampuan untuk memahami orang terkait apa yang memotivasi mereka, bagaimana mereka bekerja dan bagaimana bekerja dengan mereka secara kooperatif. Gardner (1993:23) juga menjelaskan bahwa keterampilan interpersonal dibangun dalam diri individu untuk melihat adanya perbedaan antara lain; khususnya terkait suasana hati, temperamen, motivasi, dan niat. Dalam bentuk yang lebih maju, keterampilan interpersonal memungkinkan orang dewasa yang telah cakap untuk mengetahui niat dan keinginan orang lain, bahkan meskipun hal ini telah disembunyikan oleh orang lain.

Lwin dkk. (2003:197) mengemukakan bahwa keterampilan interpersonal merupakan kemampuan untuk berhubungan dengan orang-orang disekitar kita. Artinya kemampuan untuk memahami dan memperkirakan perasan, temperamen, suasana hati, maksud, dan keinginan orang lain, kemudian menanggapinya secara layak.
Keterampilan interpersonal juga dianggap sebagai sesuatu yang harus dikembangkan melalui pembinaan dan pengajaran. Selain itu, keterampilan interpersonal memungkinkan individu untuk membangun kedekatan, pengaruh, pimpinan, dan membangun hubungan dengan masyarakat.

Gunawan (2004:118) mengemukakan bahwa individu dengan keterampilan interpersonal yang berkembang dengan baik mempunyai ciri-ciri yaitu : (1) Membentuk dan mempertahankan suatu hubungan social, (2) Mampu berinteraksi dengan orang lain, (3) Mengenali dan menggunakan berbagai cara untuk berhubungan dengan orang lain, (4) Mampu mempengaruhi tindakan dan pendapat orang lain, (5) Turut serta dalam upaya bersama dan mengambil berbagai peran yang sesuai, mulai dari menjadi seseorang pengikut hingga menjadi pemimpin, (6) Mengamati perasaan, pikiran, motivasi, perilaku, dan gaya hidup orang lain, (7) Mengerti dan berkomunikasi dengan efektif baik dalam bentuk verbal maupun nonverbal, (8) Mengembangkan keahlian untuk menjadi penengah dalam suatu konflik, mampu bekerja sama dengan orang yang mempunyai latar belakang yang beragam, (9) Tertarik untuk menekuni bidang yang berorientasi intepersonal seperti bidang pengajar, konseling, manajemen, dan politik, (10) Peka terhadap perasaan, motivasi, dan keadaan mental seseorang.

Sedangkan Armstrong mengemukakan bahwa ciri individu yang memiliki keterampilan interpersonal yang baik yaitu memiliki keterampilan interpersonal yang baik mempunyai kemampuan untuk mencerap dan tanggap terhadap suasana hati, perangai, niat, dan hasrat orang lain. Selain itu individu tersebut juga mempunyai rasa belas kasihan yang tinggi. Individu tersebut juga mampu memahami individu lain dengan melihat sudut pandang individu yang bersangkutan.

Lebih lanjut, Armstrong (2002:4) mengemukakan bahwa terdapat tiga indikator dari individu yang memiliki keterampilan interpersonal yang baik. Individu yang 
memiliki keterampilan interpersonal yang baik mempunyai kemampuan untuk mencerap dan tanggap terhadap suasana hati, perangai, niat, dan hasrat orang lain. Selain itu individu tersebut juga mempunyai rasa belas kasihan yang tinggi. Individu tersebut juga mampu memahami individu lain dengan melihat sudut pandang individu yang bersangkutan.

Kegunaan penelitian ini terbagi menjadi tiga, yaitu secara teoretis, bagi tutor, dan peneliti selanjutnya. Secara teoretis, penelitian ini memiliki kegunaan untuk memberikan sumbangan bagi pelaksanaan PKBM Se-Kecamatan Lowokwaru Malang dan menambah perbandingan penelitian tentang pendidikan luar sekolah. Bagi tutor, penelitan ini memiliki kegunanan sebagai sumbangan informasi mengenai keterampilan intrapersonal, interpersonal dan prestasi warga belajar di PKBM. Sedangkan bagi peneliti selanjutnya, penelitian ini memiliki kegunaan sebagai bahan pertimbangan untuk rujukan dalam penelitian selanjutnya khususnya berkaitan dengan perngaruh keterampilan intrapersonal dan interpersonal terhadap prestasi warga belajar di PKBM.

$$
\text { Penelitian ini memiliki }
$$

keterbatasan yaitu sampel yang digunakan hanya untuk wilayah kecamatan Lowokwaru dan tidak se-kota Malang. Selain itu, keterbatasan yang lain dari penelitian ini lebih berfokus pada warga belajar kesetaraan paket $\mathrm{C}$ dan mengabaikan warga belajar kesetaraan paket A dan B. Hal ini mengakibatkan peneliti tidak dapat menyadari adanya variabel lain yang juga mempengaruhi prestasi belajar dari warga belajar di PKBM. Peneliti juga tidak dapat membandingkan antara keterampilan intrapersonal dan interpersonal terhadap prestasi warga belajar kesetaraan paket A, B, dan C.

Keterampilan intrapersonal merupakan kemampuan individu dalam memahami segala hal yang ada pada diri individu. Individu memiliki tanggung jawab besar atas apa yang mereka inginkan, targetkan, dan ingin mereka capai. Individu yang memiliki keterampilan intrapersonal yang baik dapat dengan mudah mengakses perasaannya sendiri, membedakan berbagai macam keadaan emosi, dan menggunakan pemahamannya sendiri untuk memperkaya dan membimbing hidupnya. Keterampilan intrapersonal diukur dengan inventori keterampilan intrapersonal yang diadaptasi dari teori Keterampilan Intrapersonal menurut Thomas Armstrong. Adapun indikator dari keterampilan intrapersonal yaitu mudah membedakan dan mengendalikan berbagai macam emosi, menggunakan pemahamannya sendiri untuk memperkaya dan membimbing hidupnya, mengerti kapasitas dan kemampuan diri, disiplin dan terfokus pada tujuan, lebih suka belajar dan bekerja sendiri.

Keterampilan interpersonal merupakan jumlah keseluruhan dari kemampuan individu untuk berinteraksi secara efektif dengan individu yang lain. Individu merupakan makhluk sosial yaitu makhluk yang tidak bisa hidup sendiri, dengan kata lain individu membutuhkan individu lain untuk tetap hidup. Keterampilan interpersonal menjadi landasan individu untuk tetap mampu berkomunikasi dengan orang lain. Individu yang memiliki keterampilan interpersonal yang baik mempunyai kemampuan untuk mencerap dan tanggap terhadap suasana hati, perangai, niat, dan hasrat orang lain, mempunyai rasa belas kasihan yang tinggi. Individu tersebut juga mampu memahami individu lain dengan melihat sudut pandang individu yang bersangkutan. Keterampilan interpersonal diukur dengan inventori keterampilan interpersonal yang diadaptasi dari teori Keterampilan Interpersonal menurut Thomas Armstrong. Adapun indikator dari keterampilan interpersonal yaitu mampu menyerap dan tanggap terhadap suasana hati perangai, niat, dan hasrat orang lain, mampu berbelas kasihan dan bertanggung jawab sosial, mampu memahami orang lain dan melihat dari sudut pandang orang yang bersangkutan.

Prestasi belajar merupakan hasil usaha individu yang dapat diukur dalam bentuk nilai atau penghargaan dan dapat memberikan kepuasan tertentu pada individu sebagai 
bentuk interaksi dengan lingkungan. Prestasi belajar dapat diukur dalam dua indikator. Adapun dua hal tersebut yaitu nilai akademik dalam warga belajar kesetaraan paket $\mathrm{C}$ dan nilai non akademik yang dicapai oleh warga belajar sebelum mengikuti program belajar kesetaraan paket C. Nilai akademik dapat diketahui dari hasil rapor semester warga belajar kesetaraan paket C. Sedangkan nilai non akademik dapat diketahui dari instrumen kuesioner non akademik warga belajar kesetaraan paket $\mathrm{C}$ yang diperoleh warga belajar di sekolah sebelumnya, di masyarakat, dan di PKBM.

\section{METODE}

Pendekatan yang digunakan pada penelitian ini adalah pendekatan kuantitatif. Arikunto (2002:10) penelitian kuantitatif merupakan penelitian yang menggunakan angka mulai dari pengumpulan data, penafsiran terhadap data-data tersebut, serta penampilan dari hasilnya. Penelitian kuantitatif memiliki tujuan untuk menguji hipotesis yang telah ditetapkan oleh peneliti. Adapun metode penelitian yang digunakan dalam penelitian ini yaitu desain penelitian korelasional. Penelitian ini meneliti hubungan kausal antara variabel penelitian.

Alasan peneliti menggunakan metode penelitian ini dikarenakan peneliti ingin mencari tahu adanya hubungan dua variabel yang menyebabkan adanya pengaruh terhadap variabel yang lain. Adapun variabel yang ingin diteliti yaitu variabel bebas dan variabel terikat. Variabel bebas pada penelitian ini yaitu keterampilan intrapersonal dan interpersonal. Sedangkan, variabel terikatnya yaitu prestasi belajar. Jenis penelitian korelasional pada penelitian ini digunakan untuk menguji seberapa besar pengaruh hubungan antara keterampilan intrapersonal dan interpersonal terhadap prestasi warga belajar kesetaraan paket $\mathrm{C}$ di PKBM SeKecamatan Lowokwaru Malang.

Penelitian ini populasinya yaitu warga belajar kesetaraan paket C di PKBM SeKecamatan Lowokwaru Malang sejumlah 200 orang yang berasal dari PKBM Kartini dan
PKBM Kendedes. Alasan peneliti memutuskan warga belajar kesetaraan paket $\mathrm{C}$ di PKBM Se-Kecamatan Lowokwaru Malang menjadi subjek penelitian dikarenakan warga belajar kesetaraan paket $\mathrm{C}$ sedang berada pada masa transisi dari remaja akhir hingga dewasa awal yang sedang beradaptasi dengan lingkungan baru. Selain itu, warga belajar paket C juga memiliki karakteristik orang dewasa yaitu lebih banyak pengalaman.

Peneliti mengambil sampel penelitian dengan cara memilih sampel yang telah memenuhi beberapa kriteria. Cara ini dinamakan teknik purposive sampling. Teknik pengambilan sampel purposive yaitu teknik penentuan sampel dengan pertimbangan tertentu (Sugiyono, 2011:85). Adapun pertimbangan yang dimaksud yaitu 1) subjek penelitian merupakan warga belajar paket C yang terdaftar di salah satu PKBM se-Kecamatan Lowokwaru Malang, 2) subjek penelitian tercatat telah memiliki rapor di PKBM. Apabila ada salah satu yang tidak terpenuhi dari pertimbangan di atas maka tidak akan dijadikan sampel penelitian.

Instrumen yang digunakan pada penelitian ini yaitu inventori keterampilan intrapersonal, interpersonal, prestasi non akademik dan studi dokumentasi berupa raport. Inventori dilakukan uji validitas dan reliabilitas sehingga diperoleh item-item yang valid dan reliabel. Sedangkan studi dokumentasi dilakukan melalui kerja sama dengan pengelola PKBM terkait rapor warga belajar kesetaraan paket $\mathrm{C}$.

Adapun teknik yang digunakan dalam pengumpulan data pada penelitian ini adalah teknik pengumpulan data dengan menggunakan teknik angket. Proses pengumpulan data dalam penelitian ini dilakukan dengan memberikan inventori keterampilan intrapersonal dan interpersonal. Skala yang digunakan memiliki tujuan untuk mengumpulkan informasi dan gambaran terkait keterampilan intrapersonal dan interpersonal subjek penelitian. Adapun bentuk skala terdiri dari berbagai pernyataan yang mengarah pada keterampilan intrapersonal dan interpersonal. 
Adapun teknik analisis data yang digunakan dalam penelitian ini yaitu analisis deskriptif dan analisis korelasional. Peneliti menggunakan teknik analisis deskriptif bertujuan untuk mengetahui gambaran atau tingkat keterampilan intrapersonal dan interpersonal yang dimiliki oleh subjek penelitian (warga belajar). Hal ini dilakukan peneliti dikarenakan peneliti menggunakan skala psikologi keterampilan intrapersonal dan interpersonal. Oleh karena itu, peneliti menggunakan teknik analisis deskriptif untuk mengolah data dari hasil skala yang telah disebarkan guna mencapai tujuan ini.

Variabel dalam penelitian ini terdiri dari tiga variabel yaitu keterampilan intrapersonal (X1), keterampilan interpersonal (X2), dan prestasi belajar (Y). Sesuai dengan tujuan penelitian untuk mengetahui hubungan antara variabel-variabel tersebut maka peneliti menggunakan teknik analisis data uji Kendall Konkordansi (Kendall Coeficient of Concordance). Alasan peneliti menggunakan teknik analisis data uji Kendall Konkordansi dikarenakan hasil data berupa data ordinal. Sebelum melakukan analisis uji Kendall Konkordansi, terlebih dahulu perlu melakukan uji pendukung (uji asumsi klasik).

Adapun uji pendukung meliputi Uji Normalitas menggunakan uji KolmogorovSmirnov dan Uji Linearitas. Setelah dilakukan uji pendukung maka akan dilakukan uji Kendall Konkordansi untuk menguji hipotesis dari penelitian ini. Peneliti melakukan uji pendukung dan uji Kendall Konkordansi tersebut dengan menggunakan bantuan program SPSS 23.00 for Windows. Peneliti menganalisis hubungan antara keterampilan intrapersonal (X1) dengan prestasi belajar (Y) dan keterampilan interpersonal (X2) dengan prestasi belajar (Y) menggunakan uji korelasi Spearman. Sedangkan peneliti juga menganalisis hubungan antara keterampilan intrapersonal (X1) dan keterampilan interpersonal (X2) dengan prestasi belajar (Y) menggunakan uji Kendall Konkordansi.

\section{HASIL PENELITIAN}

Keterampilan intrapersonal dari 80 warga belajar kesetaraan paket C di PKBM Se-Kecamatan Lowokwaru Malang yang diteliti terdapat $2,4 \%$ warga belajar yang memilih "Tidak Pernah", 28,3\% warga belajar memilih "Kadang-Kadang", 29,3\% warga belajar memilih "Sering", dan 40\% warga belajar memilih "Selalu". Diketahui dari 13 aspek, aspek yang paling menonjol yaitu aspek tanggung jawab untuk melaksanakan tugas sesuai dengan apa yang menjadi kewajiban warga belajar. Sedangkan aspek yang paling rendah yaitu aspek pikiran yang cenderung melaksanakan aktivitas sendirian.

Keterampilan interpersonal dari 80 warga belajar kesetaraan paket C di PKBM Se-Kecamatan Lowokwaru Malang yang diteliti terdapat 2,4\% warga belajar yang memilih "Tidak Pernah", 28,3\% warga belajar memilih "Kadang-Kadang", 29,3\% warga belajar memilih "Sering", dan 40\% warga belajar memilih "Selalu". Dari 12 aspek, aspek yang paling menonjol yaitu aspek perasaan bahagia pada diri warga belajar ketika mampu membantu warga belajar yang lain. Sedangkan aspek yang paling rendah yaitu aspek pertanyaan yang muncul dari warga belajar kepada raut muka yang dimunculkan oleh warga belajar lain ketika berkomunikasi.

Prestasi belajar dari 80 warga belajar kesetaraan paket C di PKBM SeKecamatan Lowokwaru Malang yang diteliti menunjukkan berada pada kategori tinggi. Hal tersebut dapat diketahu dari hasil studi dokumentasi menggunakan rapor yang menunjukkan nilai rerata dari setiap warga belajar cenderung di $>$ 80. Meskipun demikian, prestasi non akademik warga belajar kesetaraan paket $\mathrm{C}$ cenderung rendah. Dari 80 warga belajar, terdapat $21,6 \%$ warga belajar yang memilih "Ya", 78,4\% warga belajar memilih "Tidak". Oleh karena itu, dapat diketahui bahwa warga belajar memiliki tingkat prestasi non akademik yang rendah. Hal itu dikarenakan pilihan jawaban warga belajar lebih banyak ke pilihan "Tidak" daripada pilihan "Ya". 


\begin{tabular}{|c|c|c|c|c|}
\hline \multicolumn{5}{|c|}{ Tabel 1. Hasil Uji Korelasi Intrapersonal dengan Prestasi Belajar } \\
\hline & & & Intrapersonal & PrestasiBelajar \\
\hline \multirow{6}{*}{ Spearman's tho } & Intrapersonal & Correlation Coefficient & 1,000 & .076 \\
\hline & & Sig. (2-tailed) & & .504 \\
\hline & & $\mathrm{N}$ & 80 & 80 \\
\hline & PrestasiBelajar & Correlation Coefficient & 076 & 1,000 \\
\hline & & Sig. (2-tailed) &, 504 & \\
\hline & & $\mathrm{N}$ & 80 & 80 \\
\hline
\end{tabular}

Hasil dari uji spearman menunjukkan bahwa tidak ada pengaruh keterampilan intrapersonal terhadap prestasi warga belajar kesetaraan paket C. Hal itu diketahui dari perolehan nilai signifikan sebesar 0,504 dengan hubungan korelasi sebesar 0,076 (sangat rendah). Apabila nilai signifikansi $<0,05, \mathrm{H}_{0}$ ditolak dan $\mathrm{H}_{\mathrm{a}}$ diterima, maka ada pengaruh yang signifikan antara keterampilan intrapersonal dengan prestasi belajar. Begitu juga sebaliknya, apabila nilai signifkansi > 0,05, $\mathrm{H}_{0}$ diterima dan $\mathrm{H}_{\mathrm{a}}$ ditolak, maka tidak ada pengaruh yang signifikan antara keterampilan intrapersonal dengan prestasi belajar. Nilai signifikansi yang diperoleh $0,504>0,05$, maka dapat diambil kesimpulan bahwa tidak ada pengaruh yang signifikan antara keterampilan intrapersonal dengan prestasi belajar.

\begin{tabular}{|c|c|c|c|c|}
\hline \multicolumn{5}{|c|}{ Tabel 2. Hasil Uji Korelasi Interpersonal dengan Prestasi Belajar } \\
\hline & & & Interpersonal & PrestasiBelajar \\
\hline \multirow[t]{6}{*}{ Spearman's tho } & Interpersonal & Correlation Coefficient & 1,000 & .023 \\
\hline & & Sig. (2-taled) & &, 839 \\
\hline & & $\mathrm{N}$ & 80 & 80 \\
\hline & PrestasiBelajar & Correlation Coefficient &, 023 & 1,000 \\
\hline & & Sig. (2-tailed) & 839 & \\
\hline & & $\mathrm{N}$ & 80 & 80 \\
\hline
\end{tabular}

Hasil dari uji spearman lain menunjukkan bahwa tidak ada pengaruh keterampilan interpersonal terhadap prestasi warga belajar kesetaraan paket C. Hal itu diketahui dari perolehan nilai signifikan sebesar 0,839 dengan hubungan korelasi sebesar 0,023 (sangat rendah). Apabila nilai signifikansi > $0,05 \mathrm{H}_{0}$ diterima dan $\mathrm{H}_{\mathrm{a}}$ ditolak, maka tidak ada pengaruh yang signifikan antara keterampilan interpersonal dengan prestasi belajar. Begitu juga sebaliknya, apabila nilai signifkansi $<0,05, \mathrm{H}_{0}$ ditolak dan $\mathrm{H}_{\mathrm{a}}$ diterima, maka ada pengaruh yang signifikan antara keterampilan interpersonal dengan prestasi belajar. Nilai signifikansi yang diperoleh $0,839>0,05$, maka dapat diambil kesimpulan bahwa tidak ada pengaruh yang signifikan antara keterampilan interpersonal dengan prestasi belajar.

Tabel 3. Hasil Uji Normalitas dengan SPSS

\begin{tabular}{|c|c|c|c|c|c|c|}
\hline \multicolumn{7}{|c|}{ Tests of Normality } \\
\hline & \multicolumn{3}{|c|}{ Kolmogorov-Smimov ${ }^{2}$} & \multicolumn{3}{|c|}{ Shapiro-Wilk } \\
\hline & Statistic & $\mathrm{df}$ & Sig. & Statistic & df & Sig. \\
\hline Intrapersonal &, 093 & 80 &, 082 &, 945 & 80 &, 002 \\
\hline Interpersonal &, 142 & 80 & 000 &, 893 & 80 &, 000 \\
\hline
\end{tabular}

a. Lilliefors Significance Correction

Berdasarkan hasil uji normalitas diperoleh nilai signifikansi pada Kolmogorov-Smirnov intrapersonal sebesar 0,082 yang artinya 0,82 $>0,05$ sehingga dapat dikatakan bahwa data intrapersonal berdistribusi normal. Sedangkan hasil uji normalitas interpersonal menunjukkan nilai signifikansi sebesar 0,000 yang artinya $0,000<0,05$ sehingga dapat dikatakan bahwa data interpersonal tidak berdistribusi normal.

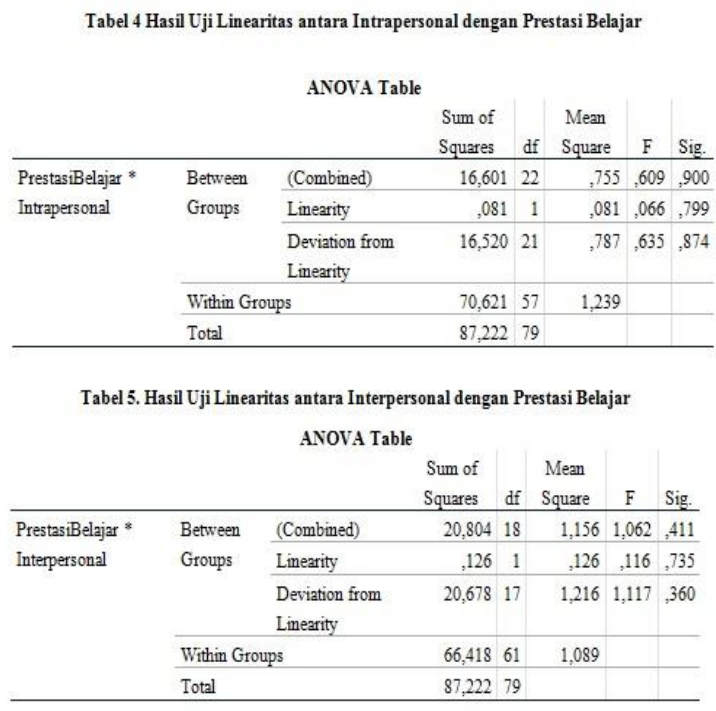

Berdasarkan hasil uji linearitas, nilai signifikansi yang diperoleh dalam kolom deviation from linearity sebesar 0,874 >0,05 sehingga dapat dikatakan bahwa terdapat hubungan yang linier antara variabel intrapersonal dengan prestasi belajar. Selain itu, hasil uji linearitas juga menunjukkan bahwa hubungan antar variabel interpersonal dengan prestasi belajar telah memenuhi asumsi linear. Hal itu dikarenakan nilai signifikansi yang diperoleh dalam kolom deviation from linearity sebesar 0,360>0,05 
sehingga dapat dikatakan bahwa terdapat hubungan yang linier antara variabel interpersonal dengan prestasi belajar.

Tabel 6. Hasil Uji Kendall Konkordansi

Test Statistics

\begin{tabular}{lr} 
N & 80 \\
\hline Kendall's W &, 792 \\
\hline Chi-Square & 126,769 \\
\hline Df & 2 \\
\hline Asymp. Sig. &, 000 \\
\hline a. Kendall's Coefficient of \\
Concordance
\end{tabular}

Sedangkan hasil uji Kendall's W diperoleh nilai sebesar sebesar 0,792 sehingga dapat dikatakan bahwa variabel keterampilan intrapersonal dan interpersonal hanya mempengaruhi variabel prestasi belajar sebesar 79,2\%. Hasil uji Kendall's juga diperoleh nilai asymp. Sig. Sebesar 0,000 yang artinya $0,000<0,05$ sehingga dapat dikatakan bahwa terdapat hubungan yang signifikan antara keterampilan intrapersonal dan interpersonal terhadap prestasi warga belajar keseteraan paket C di PKBM SeKecamatan Lowokwaru Malang.

\section{PEMBAHASAN}

Berdasarkan hasil pengumpulan data, gambaran kondisi keterampilan intrapersonal dari 80 warga belajar kesetaraan paket $\mathrm{C}$ di PKBM Se-Kecamatan Lowokwaru Malang yang diteliti terdapat 2,4\% warga belajar yang memilih "Tidak Pernah", 28,3\% warga belajar memilih "Kadang-Kadang", 29,3\% warga belajar memilih "Sering", dan $40 \%$ warga belajar memilih "Selalu". Selain itu, diketahui juga dari 13 aspek, aspek yang paling menonjol yaitu aspek tanggung jawab untuk melaksanakan tugas sesuai dengan apa yang menjadi kewajiban warga belajar. Sedangkan aspek yang paling rendah yaitu aspek pikiran yang cenderung melaksanakan aktivitas sendirian.

Menonjolnya aspek tanggung jawab untuk melaksanakan tugas sesuai dengan apa yang menjadi kewajiban warga belajar dalam keterampilan intrapersonal merupakan salah satu dari ciri orang yang memiliki keterampilan intrapersonal yang tinggi. Lwin dkk. (2003:33) mengemukakan bahwa keterampilan intrapersonal berfokus pada kemampuan individu untuk memahami dirinya dan bertanggung jawab atas kehidupannya sendiri. Selain itu, Armstrong (2002:34) juga mengemukakan bahwa keterampilan intrapersonal individu merupakan kemampuan individu untuk mengetahui siapa diri mereka dan apa yang bisa mereka bisa capai di dunia. Individu tersebut sering pandai menentukan target untuk diri sendiri. Dengan kata lain, tanggung jawab warga belajar dalam melaksanakan tugas sesuai dengan apa yang menjadi kewajibannya dianggap sebagai hasil dari tingginya keterampilan intrapersonal yang dimiliki oleh warga belajar tersebut.

Keterampilan intrapersonal diperoleh warga belajar kesetaraan paket C di PKBM berdasarkan suasana belajar yang ada di dalam PKBM. Lunandi (1986:12) mengemukakan bahwa suasana belajar di dalam pendidikan orang dewasa yang salah satunya PKBM dapat memicu warga belajar untuk penemuan diri. Penemuan diri yang dimaksud menekankan pada proses belajar oleh warga belajar apabila dirinya diberi kesempatan untuk menemukan sendiri kebutuhannya, pemecahan masalahnya, dan kesalahan-kesalahannya. Melalui proses belajar tersebut, warga belajar dapat menemukan segala kekuatan dan kelemahan dirinya. Proses ini yang mendukung keterampilan intrapersonal warga belajar kesetaraan paket $\mathrm{C}$ cenderung tinggi.

Berdasarkan hasil pengumpulan data, gambaran kondisi keterampilan interpersonal dari 80 warga belajar kesetaraan paket $\mathrm{C}$ di PKBM Se-Kecamatan Lowokwaru Malang yang diteliti terdapat 2,4\% warga belajar yang memilih "Tidak Pernah", 28,3\% warga belajar memilih "Kadang-Kadang", 29,3\% warga belajar memilih "Sering", dan 40\% warga belajar memilih "Selalu". Selain itu, diketahui juga dari 12 aspek, aspek yang paling menonjol yaitu aspek perasaan bahagia pada diri warga belajar ketika mampu membantu warga belajar yang lain. Sedangkan aspek yang paling rendah yaitu aspek pertanyaan 
yang muncul dari warga belajar kepada raut muka yang dimunculkan oleh warga belajar lain ketika berkomunikasi.

1. Menonjolnya aspek perasaan bahagia pada diri warga belajar ketika mampu membantu warga belajar yang lain dalam keterampilan interpersonal merupakan salah satu ciri tingginya keterampilan interpersonal warga belajar. Lwin dkk. (2003:197) mengemukakan bahwa keterampilan interpersonal merupakan kemampuan untuk berhubungan dengan orangorang disekitar kita. Artinya kemampuan untuk memahami dan memperkirakan perasan, temperamen, suasana hati, maksud, dan keinginan orang lain, kemudian menanggapinya secara layak. Sedangkan Armstrong (2002:32) mengemukakan bahwa keterampilan interpersonal merupakan kemampuan individu untuk bisa memahami individu yang lain. Individu tersebut mampu mengorganisir, mengkomunikasikan dan memanipulasi individu yang lain. Individu juga mampu memahami apa yang dipikirkan, dirasakan, dan dilakukan orang lain. Dengan kata lain, warga belajar yang mampu membantu warga belajar yang lain itu merupakan hasil dari tingginya keterampilan interpersonal yang dimilikinya. Ketika warga belajar mampu memahami warga belajar yang lain, akan muncul perasaan yang cenderung positif dari dalam dirinya.

Keterampilan interpersonal yang diperoleh warga belajar kesetaraan paket C di PKBM merupakan hasil dari belajar. Lunandi (1986:8) mengemukakan bahwa belajar merupakan suatu hasil kerja sama antara manusia. Dua atau lebih banyak warga belajar yang saling memberi dan menerima hasil belajar yang diperoleh selama pembelajaran di PKBM. Hal itu dikarenakan di dalam kerja sama itu terdapat pertukaran pengalaman, pertukaran pengetahuan, dan saling mengungkapkan reaksi serta tanggapannya mengenai suatu masalah.

Berdasarkan hasil pengumpulan data, gambaran kondisi prestasi belajar dari 80 warga belajar kesetaraan paket C di PKBM Se-Kecamatan Lowokwaru Malang yang diteliti hampir mayoritas memiliki rerata di atas nilai 80. Nilai tersebut tergolong prestasi belajar akademik yang cenderung tinggi. Tingginya prestasi belajar akademik disebabkan oleh adanya motivasi internal dan eksternal. Basleman (2011:29) mengemukakan bahwa motivasi mempunyai beberapa tujuan, yaitu memberikan semangat untuk meningkatkan kemampuan belajar, meningkatkan saling pengertian dan interaksi antara subjek dan objek didik, meningkatkan efektivitas dan efesiensi pelaksanaan kegiatan untuk mencapai tujuan yang diinginkan. Dengan kata lain, tingginya prestasi belajar akademik warga belajar kesetaraan paket $\mathrm{C}$ dikarenakan warga belajar memiliki semangat yang tinggi dalam meningkatkan kemampuan belajarnya ketika di PKBM.

Meskipun prestasi belajar akademik warga belajar kesetaraan paket $\mathrm{C}$ cenderung tinggi, hal tersebut tidak terjadi serupa dengan prestasi belajar non akademik warga belajar paket $\mathrm{C}$. Berdasarkan hasil pengumpulan data, dari 80 warga belajar kesetaraan paket $\mathrm{C}$ di PKBM Se-Kecamatan Lowokwaru Malang yang diteliti terdapat $21,6 \%$ warga belajar yang memilih "Ya", 78,4\% warga belajar memilih "Tidak". Oleh karena itu, dapat diketahui bahwa warga belajar memiliki tingkat prestasi non akademik yang rendah. Hal itu dikarenakan pilihan jawaban warga belajar lebih banyak ke pilihan "Tidak" daripada pilihan "Ya".

Rendahnya prestasi belajar non akademik juga disebabkan adanya bakat yang berbedabeda dari setiap warga belajar. Basleman (2011:29) mengemukakan bahwa bakat merupakan salah satu faktor yang mempengaruh prestasi warga belajar. Hal itu dikarenakan warga belajar memang memiliki bakat tersendiri, namun minimnya pihak yang mewadahi warga belajar untuk menyalurkan dan mengembangkan bakatnya menjadi bukti 
mengapa prestasi non akademik warga belajar kesetaraan paket $\mathrm{C}$ cenderung rendah.

PKBM merupakan salah satu bentuk pendidikan untuk orang dewasa. Lunandi (1986:1) mengemukakan bahwa pendidikan orang dewasa dikenal sebagai keseluruhan proses pendidikan yang diorgansasikan, baik formal maupun tidak, yang melanjutkan maupun menggantikan pendidikan semula disekolah. Melalui pendidikan orang dewasa di PKBM dapat membuat orang yang dianggap dewasa oleh masyarakat untuk memperkaya pengetahuannya. Dengan kata lain, PKBM telah mewadahi orang dewasa untuk memperoleh lebih banyak pengetahuan yang dibuktikan dengan prestasi belajar.

Tidak adanya pengaruh antara keterampilan intrapersonal dengan prestasi belajar dikarenakan adanya perbedaan karakteristik antar warga belajar yang cenderung individual. Basleman \& Mappa (2011:16) mengemukakan bahwa warga belajar memiliki karakteristik yang berbedabeda ketika mengikuti kegiatan belajar. Adapun perbedaan tersebut meliputi kepribadian, gaya belajar, dan perbedaan individual. Perbedaan-perbedaan ini diasumsikan menjadi landasan mengapa tidak pengaruh antara keterampilan intrapersonal dengan prestasi belajar.

Tidak adanya pengaruh antara keterampilan interpersonal dengan prestasi belajar dikarenakan adanya faktor perbedaan cara berkomunikasi antar warga belajar. Basleman \& Mappa (2011:16) mengemukakan bahwa pergaulan warga belajar dengan warga belajar lain di tempat kegiatan belajar berlangsung memunculkan pandangan yang berbeda. Pandangan yang berbeda ini memunculkan kepribadian yang berbeda-beda pula sehingga setiap warga belajar memiliki cara merencanakan, mengikuti, dan menilai kegiatan belajar yang ada di PKBM. Oleh karena itu, kuat tidaknya keterampilan interpersonal pada diri warga belajar tidak mempengaruhi prestasi belajar yang dimilikinya dikarenakan adanya perbedaan dalam diri warga belajar.
Adanya pengaruh keterampilan intrapersonal dan interpersonal terhadap prestasi warga belajar kesetaraan paket $\mathrm{C}$ di PKBM Se-Kecamatan Lowokwaru Malang juga dijelaskan secara teoretis. PKBM merupakan pendidikan non formal yang berbeda dengan pendidikan formal. Hal itu sependapat dengan Kamil (2011:5) bahwa pendidikan non formal dirasakan lebih ideal dan lebih respect dibandingkan dengan pendidikan formal. Pendidikan non formal dengan ciri lebih respect ini, pendidikan non formal diharapkan mampu melayani pendidikan mulai tingkat dasar hingga tingkat menengah dan diutamakan bagi para pemuda yang tidak sekolah atau drop out dan tidak berada pada usia sekolah formal.

Selain itu, PKBM juga memiliki fungsi yang menjadi alasan mengapa terdapat pengaruh keterampilan intrapersonal dan interpersonal terhadap prestasi belajar. Adapun fungsi yang dimaksud yaitu PKBM sebagai tempat tukar belajar (learning exchange). Kamil (2011:89) mengemukakan bahwa PKBM merupakan tempat terjadinya pertukaran berbagai informasi (pengalaman), ilmu pengetahuan, dan keterampilan antar warga belajar. Dengan kata lain, hal ini juga berkaitan dengan apa saja yang harus diperhatikan dengan kondisi warga belajar. Salah satunya yaitu motivasi.

Motivasi menjadi suatu faktor yang perlu menjadi perhatian dalam pendidikan non formal (PKBM). Secara teoretis, motivasi belajar dari kata motif yang diartikan sebagai keadaan dalam pribadi orang yang mendorong individu untuk melakukan aktifitas-aktifitas tertentu guna mencapai suatu tujuan (Maslow,). Hal ini sependapat dengan Kamil (2011:63) bahwa tanpa adanya motivasi dalam diri warga belajar, secanggih apapun fasilitas maupun model pembelajaran yang digunakan tutor, proses pembelajaran tidak akan berlangsung hangat, partisipatif, dan mungkin hasil pembelajaran di PKBM tidak akan sesuai dengan tujuan yang ditetapkan.

Setiap warga belajar memiliki motivasi belajar yang beraneka ragam. keanekaragaman tersebut tidak hanya 
dikarenakan masalah drop out dari pendidikan formal. Melainkan adanya pengalamanpengalaman negatif yang telah dialami oleh warga belajar. Hal ini sependapat dengan Marzuki (2009:105) bahwa program PKBM sangat cocok untuk warga belajar yang tidak betah di sekolah, yang dianggapnya mengurangi kemerdekaan mereka.

Selain itu, warga belajar kesetaraan paket $\mathrm{C}$ juga memiliki persepsi yang lain. Adapun persepsi yang dimaksud yaitu, keinginan untuk mendapatkan ijazah. Secara tidak langsung, hal ini sependapat dengan pendapat Marzuki (2009:107) bahwa pendidikan non formal seringkali dianggap sebagai pendidikan untuk pengganti pendidikan yang setara atau pendidikan untuk mencari nafkah. Hal ini juga diperkuat dengan hasil wawancara pasca penelitian kepada salah satu warga belajar bahwa warga belajar kesetaraan paket $\mathrm{C}$ mengikuti pembelajaran di PKBM hanya untuk mendapat ijazah. Ijazah ini menjadi syarat agar warga belajar dapat bertahan hidup secara layak.

Persepsi yang dimiliki warga belajar merupakan salah satu bentuk dari keterampilan intrapersonal. Gardner (1993:24) menjelaskan bahwa keterampilan intrapersonal lebih menekankan pada pengetahuan tentang aspek internal seseorang. Dengan kata lain, warga belajar telah memahami dirinya sendiri hingga dapat memunculkan persepsi positif. Persepsi yang positif ini akan memunculkan motivasi dalam diri warga belajar untuk mencapai tujuannya di PKBM.

Motivasi ini semakin diperkuat dengan adanya kehadiran warga belajar yang lain. Hal itu dikarenakan warga belajar saling memiliki tujuan yang sama, harapan yang sama, dan saling berempati satu sama lain. Tentunya hal ini berkaitan dengan salah satu keterampilan yaitu keterampilan interpersonal. Gardner (1993:9) mengemukakan bahwa keterampilan interpersonal merupakan kemampuan untuk memahami orang terkait apa yang memotivasi mereka, bagaimana mereka bekerja dan bagaimana bekerja dengan mereka secara kooperatif. Pendapat di atas didukung oleh
Armstrong (2002:33) yang mengemukakan salah satu ciri individu memiliki keterampilan interpersonal yaitu berempati besar terhadap perasaaan orang lain.

Kombinasi antara keterampilan intrapersonal dan interpersonal merupakan salah satu gagasan yang dimunculkan oleh Howard Gardner. Melalui bukunya Multiple Intelligences, Gardner mengemukakan bahwa di dalam diri individu, terdapat sembilan kecerdasan yang dimiliki individu. Dengan kata lain, setiap warga belajar tentunya memiliki perbedaan dalam tingkat kecerdasan mana yang paling menonjol. Namun, ada juga yang memiliki dua atau lebih kecerdasan yang menonjol daripada kecerdasan yang lain.

Secara tidak langsung, adanya dua keterampilan yaitu keterampilan intrapersonal dan interpersonal memberikan pengaruh terhadap prestasi belajar. Ketika warga belajar memiliki motivasi yang tinggi, dirinya akan memiliki dorongan dalam diri untuk menggapai apa yang diinginkannya. Apabila ditambah dengan motivasi eksternal yang didapat dari warga belajar, motivasi ini akan kuat dan semakin mendorong warga belajar untuk mengikuti pengalaman warga belajar lain dalam mencapai prestasi belajar baik secara akademik maupun non akademik.

Selain itu, dua keterampilan intrapersonal dan interpersonal ini dapat menjadi pendukung untuk evaluasi bersama dan evaluasi diri. Lunandi (1986:13) mengemukakan bahwa pendidikan orang dewasa yang salah satunya PKBM dapat memfasilitasi warga belajar untuk mengetahui kekurangan dan kelebihan, baik dirinya maupun orang lain melalui kelompok pembelajaran. Evaluasi bersama akan terbentuk di dalam pembelajaran tersebut dan akan diperoleh suatu renungan. Renungan ini, dapat menjadi acuan untuk warga belajar dalam mengevaluasi dirinya dengan bantuan orang lain.

\section{SIMPULAN}

Gambaran kondisi keterampilan intrapersonal warga belajar kesetaraan paket $C$ di PKBM Se-Kecamatan Lowokwaru 
Malang cenderung tinggi. Warga belajar memiliki motivasi yang kuat dari dalam dirinya sebagai bentuk dari keterampilan intrapersonal. Hal tersebut diketahui dari tingginya aspek yang paling menonjol dari keterampilan intrapersonal yaitu aspek tanggung jawab untuk melaksanakan tugas sesuai dengan apa yang menjadi kewajiban warga belajar.

Gambaran kondisi keterampilan interpersonal warga belajar kesetaraan paket $C$ di PKBM Se-Kecamatan Lowokwaru Malang cenderung tinggi. Motivasi ini semakin diperkuat dengan adanya motivasi dari warga belajar yang lain sebagai bentuk dari hasil keterampilan interpersonal yang dimilikinya. Hal tersebut diketahui dari tingginya aspek yang paling menonjol dari keterampilan interpersonal yaitu aspek perasaan bahagia pada diri warga belajar ketika mampu membantu warga belajar yang lain.

Gambaran kondisi prestasi warga belajar kesetaraan paket C di PKBM Se-Kecamatan Lowokwaru Malang cenderung tinggi pada bidang akademik. Hal itu dikarenakan adanya motivasi yang dapat mendorong warga belajar untuk meningkatkan prestasi belajarnya di PKBM.

Selain itu, hasil penelitian membuktikan bahwa tidak ada pengaruh keterampilan intrapersonal terhadap prestasi warga belajar kesetaraan paket C di PKBM Se-Kecamatan Lowokwaru Malang. Hasil penelitian membuktikan bahwa tidak ada pengaruh keterampilan interpersonal terhadap prestasi warga belajar kesetaraan paket C di PKBM Se-Kecamatan Lowokwaru Malang. Hasil penelitian juga membuktikan bahwa ada pengaruh antara keterampilan intrapersonal dan interpersonal dengan prestasi warga belajar kesetaraan paket $\mathrm{C}$ di PKBM SeKecamatan Lowokwaru Malang.

\section{SARAN}

Pihak pengelola PKBM perlu mengadakan kegiatan semacam forum komunikasi antara warga belajar dengan tutor yang berisikan kegiatan sharing. Mengingat hasil penelitian menunjukkan bahwa ada pengaruh keterampilan intrapersonal dan interpersonal terhadap prestasi belajar. Dengan adanya kegiatan sharing ini, pihak PKBM dapat mengetahui apa yang menjadi keinginan dan harapan dari setiap warga belajar dalam menempuh pendidikan di PKBM.

Pihak tutor perlu memahami kebutuhan warga belajar ketika proses pembelajaran sedang berlangsung. Mengingat warga belajar membutuhkan strategi yang beraneka ragam. Hal itu dilakukan agar warga belajar tertarik untuk belajar lebih dalam, sehingga warga belajar memiliki motivasi yang tinggi untuk mengikuti pembelajaran.

Peneliti lain disarankan untuk melakukan tindakan lebih lanjut mengenai motivasi warga belajar kesetaraan paket $\mathrm{A}, \mathrm{B}$, dan $\mathrm{C}$ dalam mengikuti pembelajaran di PKBM. Mengingat pada penelitian ini hanya berfokus pada warga belajar kesetaraan paket C. Selain itu, disarankan bagi peneliti lain untuk menggunakan metode penelitian yang lain yaitu pendekatan kualitatif. Hal itu dikarenakan mengingat keterbatasan dari penelitian ini sebagai bahan pertimbangan untuk perbaikan dan penyempurnaan penelitian yang akan dilakukan.

Jurusan Pendidikan

Luar Sekolah disarankan untuk bekerja sama dengan PKBM di manapun dengan tujuan memfasilitasi warga belajar untuk mengembangkan segala kompetensi yang dimilikinya. Kompetensi ini juga menunjang kelancaran warga belajar dalam mengikuti pembelajaran di PKBM.

\section{DAFTAR PUSTAKA}

Arif, Z. 1986. Andragogi. Bandung: Angkasa.

Arifin, Z. 1988. Evaluasi Instruksional : Prinsip-Teknik-Prosedur. Bandung : Remadja Karya.

Arikunto, S. 2002. Prosedur Penelitian : Suatu Pendekatan Praktek. Jakarta : Rineka Cipta.

Arikunto, S. 2010. Prosedur Penelitian : Suatu Pendekatan Praktek. Jakarta : Rineka Cipta. 
Arikunto, S. 2012. Prosedur Penelitian : Suatu Pendekatan Praktek. Jakarta : Rineka Cipta.

Armstrong, T. 2002. Kinds of Smart : Menemukan dan Meningkatkan Kecerdasan Anda Berdasarkan Teori Multiple Intelligence. Jakarta : PT Gramedia Pustaka Utama.

Armstrong, T. 2002. Setiap Anak Cerdas : Panduan Membantu Anak Belajar dengan Memanfaatkan Multiple Intellegence. Jakarta : PT Gramedia Pustaka Utama.

Azwar, S. 2004. Pengantar Psikologi Inteligensi. Yogyakarta : Pustaka Belajar.

Basleman, A. \& Mappa, S. 2011. Teori Belajar Orang Dewasa. Bandung : Remaja Rosdakarya.Sugiyono. 2011. Metode Penelitian Kuantitatif dan Kualitatif dan $R \& D$. Bandung: Alfabeta.

Gardner, H. 1993. Multiple Intelligences : The Theory in Practice. United States of America : HarperCollins.

Gunawan, A. W. 2004. Born To Be a Genius. Jakarta : PT Gramedia Pustaka Utama.

Hoerr, T. R. 2007. Buku Kerja Multiple Intelligences (Diterjemahkan oleh Ary Nilandari). Bandung : Kaifa

Imroatusholikhah. 2016. Hubungan Kecerdasan Interpersonal dan Kecerdasan Intrapersonal terhadap Hasil Belajar Matematika Siswa MTs Ma'arif Kencong. Skripsi tidak diterbitkan. Malang : Fakultas Matematika dan Ilmu Pengetahuan Alam Universitas Negeri Malang.

Johnson, D. W. 1972. Reaching Out : Interpersonal Effectiveness and SelfActualization. Englewoof Cliffs : PrentieHall.

Kamil, 2011. Pendidikan Nonformal : Pengembangan Melalui Pusat Kegiatan Belajar Mengajar (PKBM) di Indonesia. Bandung : Alfabeta.

Lunandi, A.G. 1986. Pendidikan Orang Dewasa: Sebuah Uraian Praktis untuk Pembimbing, Penatar, Pelatih, dan Penyuluh Lapangan. Jakarta : Gramedia.
Lwin, dkk. 2003. Cara Mengembangkan Berbagai Komponen Kecerdasan. Jakarta : Indeks.

Marzuki, M. S. 2009. Pendidikan Nonformal Bukan Residu. Malang : FIP UM.

Mulyono. 2008. Manajemen Administrasi \& Organisasi. Jogjakarta : Arruz Media.

Rakhmat, J. 2000. Psikologi Komunikasi. Bandung : Remadja Karya.

Sugiyono, 2011. Metode Penelitian Kuantitatif, Kualitatif, dan $R \& D$. Bandung : Alfabeta.

Winkel. W. S. 1991. Psikologi Pengajaran. Jakarta : Grasindo. 